\title{
IMPACT OF EXCHANGE RATE ON BALANCE OF PAYMENTS IN NIGERIA
}

\author{
Nwachukwu Nnamdi \\ Department of Economics/Faculty of Management and Social Sciences/Godfrey Okoye \\ University Enugu. Email: nnamdinwachukwu83@ gmail.com
}

\section{Cite this article:}

Nwachukwu Nnamdi (2021), Impact of Exchange Rate on Balance of Payments in Nigeria. African Journal of Economics and Sustainable Development 4(2), 104-118. DOI: $10.52589 / A J E S D-$ SDEWBA5E.

\section{Manuscript History}

Received: 15 July 2021

Accepted: 24 Aug 2021

Published: 31 Aug 2021

Copyright $\odot 2020$ The Author(s). This is an Open Access article distributed under the terms of Creative Commons AttributionNonCommercial-NoDerivatives 4.0 International (CC BY-NC-ND 4.0 ), which permits anyone to share, use, reproduce and redistribute in any medium, provided the original author and source are credited.
ABSTRACT: This study examined the impact of exchange rate on balance of payments in Nigeria. Data for the study which are balance of payments, exchange rate, interest rate, trade openness and crude oil price were extracted from the Central Bank of Nigeria (CBN) statistical bulletin covering the period 1981-2019. The method of data analysis is the Vector Error Correction Mechanism (VECM). The results reveal that there is a positive relationship between balance of payments and exchange rate in Nigeria, exchange rate has significant impact on balance of payments in Nigeria $(t$-stat $=2.47441)$ and there is causality relationship between exchange rate fluctuations and balance of payments in Nigeria $(p$-value $=0.0174<0.05)$. It is therefore the recommendation of this study that the government should encourage make political and industrial peace and stability a top macro-political policy priority.

KEYWORDS: Exchange Rate, Balance of Payments and Crude Oil Price 


\section{INTRODUCTION}

In ordinary parlance, the balance of payments of a country is a statistical and systematic record of all its economic transactions with the outside world in a fiscal year, usually one year. It is a statistical record of the character and dimensions of the country's economic relationships with the rest of the world. However, the balance of payments of a country is affected by other macroeconomic variables like the price of their currency at the international money market (exchange rate), Gross Domestic Product (GDP), inflation, interest rate, etc. However, based on the context of this research, the researcher is motivated to investigate the impact of exchange rates on the balance of payments in Nigeria.

In the macroeconomic management of any economy, the exchange rate occupies a significant position as an important macroeconomic tool or target policy. Olanipekun and Ogunsola (2017) asserted that exchange rate movement and policy have multidimensional effects covering both the internal and external balances of a nation or country. Movements and changes in the exchange rate of a country have macroeconomic implications for the balance of payments position of a country and even its economic growth and income distribution. The exchange rate facilitates the exchange of goods and services during international trade and hence sustains international competitiveness and sustains balance of payments viability (CBN, 2015). Oladipupo and Ogbenovo (2011) posit that the exchange rate is relevant in international relations because it primarily interconnects the monetary unit of participating countries together, thereby making possible, the possibility of the exchange of goods and services.

In Nigeria, prior to the time of deregulation which resulted in the Structural Adjustment Programme (SAP), it looked like Nigerian's exchange rate position and policy appeared to encourage naira-overvaluation. This is because, in the year1981, the exchange rate was 0.90 cents to $\mathrm{N} 1$. This, therefore, encouraged importation and discouraged non-oil export and resulted in the over-dependence of the Nigerian economy on importation of inputs over the exportation of output. Given this scenario, it was obvious that the imports exceeded exports and given such a position, the country's balance of payments will be a deficit and hence, its currency will be devalued against other trading partners.

The changes and movements in the exchange rate and its relationship with the balance of payments has attracted the attention of policymakers, scholars, experts and financiers (Nwanosike, Uzoechina, Ebenyi \& Ishiwu, 2017). The maintenance of the balance of payments is the major aim and priority of the exchange rate policy. This is because the underperformance in the balance of payments of a country can have an impending effect on a country's reserves and economic development. This was why Shafi, Hua, Idrees and Nazeer (2015) emphasized that a country's external performance is largely measured with the status of its balance of payments and this deeply determines its strengths and trade position.

However, the effect of the exchange rate on the balance of payments is not one way. The overreliance of Nigeria on oil has some macroeconomic implications which affect both the exchange rate and balance of payments. This is because the mono-cultural nature of the Nigerian economy which led to the neglect of the agricultural sector have constituted much harm to the country's currency which has kept fluctuating against major currencies of the world like the dollar, pounds sterling and euro which Nigeria has strong international trade relationship with. 
Government in an attempt to minimize the adverse effect of Naira appreciation on the balance of payments and international trade balance which continued to be in deficit and resulted in devaluing the Naira with other currencies of the world. In the year 2019, the United States dollar was averagely exchanging for $\mathrm{N} 306.8$, pounds sterling for $\mathrm{N} 401.7958$ while Euro and SWISS FRANCS are being exchanged for $\mathrm{N} 358.9152$ and $\mathrm{N} 308.9069$ respectively (CBN, 2018).

Despite the policy engagements and thrusts of Nigerian governments, the country has been experiencing massive fluctuating exchange rates which adversely affected the level of balance of payments. Achieving a stable exchange rate that is expected to yield a favourable balance of payments and achieve sustainable economic growth and development has been a challenge for policymakers in the country (Onoh, 2002; Nnanna, 2004; Ogbonna, 2010).

Over the years, Nigeria has been experiencing lingering discrepancies in its balance of payments and is also faced many limitations in taking monetary and fiscal actions to ameliorate this state due to her over-dependency on imported goods and services. This undesirable situation continued to get worse from the year 2008 with a current account balance amounting to $\mathrm{N} 3,455.7$ billion, $\mathrm{N} 2,064.9$ billion in 2009 , in 2010 , it amounted to $\mathrm{N} 1,970.6$ billion, $\mathrm{N} 1,641.5$ billion in 2011, in 2012, it was $\mathrm{N} 2736.4$ billion, $\mathrm{N} 2,99.6$ billion in 2013, and in 2014 it amounted to $\$ 142.6$ billion and an unfavourable balance of $\$ 3,033.5$ billion in 2015 before making an improvement to $\mathrm{N} 687.9$ billion in 2016 and $\$ 3,174.4$ billion in 2017 and later reduced to $\mathrm{N} 1,630.1$ billion in 2018 (CBN, 2018).

The macroeconomic relationship between exchange rate movements and the performance of balance of payments has drawn the attention of empirical studies. However, it is discovered that most of the reviewed studies did not take cognizance of the effect of crude oil price on the exchange rate and hence, on the balance of payments. However, in Nigeria, the level of balance of payments frequently tilts to the dimension of being unfavourable (Obadan, 2018). In most cases, imports tend to exceed exports and this is not healthy for an economy like Nigeria. Many factors have been attributed to be the root cause of this quagmire. It was felt that the depreciation of naira would relieve pressures on the balance of payment. Consequently, the Nigerian currency (Naira) was devalued and the irony of this policy instrument is that Nigeria's foreign trade structure did not adequately satisfy the conditions for a successful balance of payment policy. Previous researchers who researched the effect of the exchange rate on the balance of payments in Nigeria have ignored the destructive effect of crude oil prices. Nigeria economy being an oil-dependent economy is subject to the fluctuations of the price of its primary export (crude oil) and this has a spillover effect on the exchange rate, the balance of payments and the economy at large. This study is, therefore, aimed at carrying out an empirical analysis of the impact of exchange rate on the balance of payments covering the period 19812019 bearing in mind the effect of crude oil as a major control variable.

\section{LITERATURE REVIEW}

The exchange rate is seen as the price of one currency in terms of another. It is what a currency is valued at the international currency market or the price of a currency in terms of a group of currencies or currency standards. On the other hand, the balance of payments is a systematic record of a country's international financial and economic transaction and trade position with 
respect to other nations of the world (Imoisi, 2012). The impact of proper exchange rate management in facilitating economic growth and development cannot be overemphasized. This is because exchange rate movement has a significant impact on other macroeconomic variables such as interest rate, inflation, money supply, and balance of payments position. The management of the exchange rate is of great macroeconomic importance to policymakers given the fact that no economy exists in isolation and every nation places equilibrium in the balance of payments as part of its macroeconomic priorities.

Mbanasor and Obioma (2017) carried out a study on the impact of exchange rate fluctuations on Nigeria's balance of payment in Nigeria. The two-stage least squares statistical analysis was utilized. The major findings of the study indicated that exchange rate fluctuations have a positive and insignificant impact on Nigeria's balance of payments in Nigeria.

Echekoba (2016) empirically examined the effect of exchange rates on balance of payments (BOP) in Nigeria from 1990-2013. The econometrics tools employed in the study are multiple regression statistical analysis, unit-root test and cointegration technique. The major findings of the study were that the exchange rate has a significant impact on the balance of payments.

Dayo and Akindele (2016) carried out a study on the impact of exchange rate on aggregate balance of payment (BOP), capital account and current account balance in Nigeria. Autoregressive Distributed Lag (ARDL) approach to cointegration was adopted to estimate the models. This was followed by the short-run error correction model. The study finds that exchange rate appreciation had an adverse effect on BOP and current account balance.

\section{METHODOLOGY}

\section{Research Design}

The investigation employed the Ex Post Facto design given that it is targeted at analyzing the impact of some independent variables on a specified dependent variable. This study makes use of the econometric procedure in estimating exchange rate fluctuations and balance of payments in Nigeria. It is also pertinent to note that the research design adopted the quantitative approach based on the fact that it gave room for statistical and econometric analysis of the model.

\section{Theoretical Framework}

This study is anchored on the balance of payments theory of exchange. The balance of payments theory of exchange rate propounded by Krueger in 1969 holds that the price of foreign money in terms of domestic money is determined by the free forces of demand and supply in the foreign exchange market.

\section{Model Specification}

The model used by Samuel (2017) serves as a mirror to the present study. The model he adopted is made up of the following functional relationship: $\mathrm{BOP}=\mathrm{f}(\mathrm{ERX}, \mathrm{IR}, \mathrm{INF}, \mathrm{OPN})$. The present study adjusted the equation by removing inflation and adding crude oil price (COP) to reflect the gap observed in the present study. Therefore, the stochastic form of the present model becomes: 
In implicit form: $B O P_{t}=f\left(E X R_{t}, I R_{t} O P N, C O P\right)$

Transforming equation 3.1 into an explicit econometric form, we have:

$$
B O P_{t}=\beta_{0}+\beta_{1} E X R_{t}+\beta_{2} I R_{t}+\beta_{3} O P N_{t}+\beta_{4} C O P_{t}+\mu_{t}
$$

Where:

$\mathrm{BOP}=$ Balance of Payments

$\mathrm{EXR}=$ Exchange Rate

$\mathrm{IR}=$ Interest Rate

OPN $=$ Trade Openness

$\mathrm{COP}=$ Crude Oil Price

$\mathrm{t}=$ Time

$\mu=$ Stochastic Error Term

\section{Data Estimation Techniques}

The study utilized the Vector Error Correction Mechanism (VECM) to estimate the relationship between exchange rate and balance of payment. However, given that the study used time-series data, the secondary data are subjected to unit-root/stationary test using Augmented DickeyFuller test.

Furthermore, this study employed the Johansen method of cointegration to analyze if the variables have a long-run relationship. To test the validity and reliability of the regression coefficients, the regression model was subjected to post-estimation tests namely; serial correlation test using Breusch-Godfrey Serial Correlation LM Test, normality test, Heteroskedasticity test using Breusch-PaganGodfrey and stability test using the unit-Circle.

\section{RESULTS AND ANALYSIS}

\section{Unit-Root Test}

The Augmented Dickey-Fuller (ADF) unit root test was used to determine the stationarity of the data. The results of the unit-root test are reported in Table 4.1 below.

Table 4.1: Unit Root Test Result

\begin{tabular}{|l|l|l|l|}
\hline VARIABLE & ADF STAT. & CRITICAL VAL. & ORDER \\
\hline BOP & -5.509096 & -3.574244 & $\mathrm{I}(1)$ \\
\hline EXR & -4.815163 & -3.536601 & $\mathrm{I}(1)$ \\
\hline IR & -2.999236 & -1.952066 & $\mathrm{I}(1)$ \\
\hline OPN & -6.200703 & -2.943427 & $\mathrm{I}(1)$ \\
\hline COP & -5.521153 & -2.943427 & $\mathrm{I}(1)$ \\
\hline
\end{tabular}

Source: Author's Computation Using E-views 10. 
Table 4.1 clearly shows that all the variables are stationary at the first difference (I(1)). This means that the variables have unit-root until differenced in the first order. This was also strengthened by the correlogram analysis.

\section{Optimal Lag Selection}

\section{Table 4.2}

\section{VAR Lag Order Selection Criteria}

Endogenous variables: BOP EXR IR OPN COP

Exogenous variables: $\mathrm{C}$

Date: 08/04/21 Time: 21:26

Sample: 19812019

Included observations: 36

\begin{tabular}{ccccccc}
\hline Lag & LogL & LR & FPE & AIC & SC & HQ \\
\hline & & & & & & \\
0 & -676.1962 & NA & $1.88 \mathrm{e}+10$ & 37.84424 & 38.06417 & 37.92100 \\
1 & -540.0637 & 226.8875 & 39686303 & 31.67021 & $32.98981^{*}$ & 32.13078 \\
2 & -507.4716 & $45.26681^{*}$ & $28341616^{*}$ & 31.24842 & 33.66769 & $32.09281^{*}$ \\
3 & -478.8017 & 31.85542 & 29158847 & $31.04454^{*}$ & 34.56347 & 32.27274 \\
\hline
\end{tabular}

* indicates lag order selected by the criterion

LR: sequential modified LR test statistic (each test at 5\%

level)

FPE: Final prediction error

AIC: Akaike information criterion

SC: Schwarz information criterion

HQ: Hannan-Quinn information criterion

Source: Researcher's Computation Using E-views

The first step in estimating an econometric model is to select the optimal lag length for the analysis. Selecting a lag length arbitrarily may lead to estimates that are biased and inconsistent. As seen from table 4.2, it can be clearly seen that Schwarz Information Criterion (SC) recommended lag one, Akaike Information Criterion (AIC) recommended lag three while sequentially modified LR test statistic, Final Prediction Error (FPE) and Hannan-Quinn Information Criterion (HQ) recommended lag two. Going by the majority, the optimum lag length for the study is lag two. 


\section{Cointegration Analysis (Johansen Methodology)}

\section{Table 4.3: Cointegration Test Result}

Date: 08/04/21 Time: 21:39

Sample (adjusted): 19842019

Included observations: 36 after adjustments

Trend assumption: Linear deterministic trend

Series: BOP EXR IR OPN COP

Lags interval (in first differences): 1 to 2

Unrestricted Cointegration Rank Test (Trace)

\begin{tabular}{ccccc}
\hline $\begin{array}{c}\text { Hypothesized } \\
\text { No. of CE(s) }\end{array}$ & Eigenvalue & $\begin{array}{c}\text { Trace } \\
\text { Statistic }\end{array}$ & $\begin{array}{c}0.05 \\
\text { Critical Value }\end{array}$ & Prob.** \\
\hline & & & & \\
\hline None * & 0.687101 & 75.29389 & 69.81889 & 0.0171 \\
At most 1 & 0.344310 & 33.46645 & 47.85613 & 0.5311 \\
At most 2 & 0.238656 & 18.27205 & 29.79707 & 0.5460 \\
At most 3 & 0.202529 & 8.455920 & 15.49471 & 0.4180 \\
At most 4 & 0.008541 & 0.308780 & 3.841466 & 0.5784 \\
& & & & \\
\hline
\end{tabular}

Trace test indicates 1 cointegrating eqn(s) at the 0.05 level

* denotes rejection of the hypothesis at the 0.05 level

**MacKinnon-Haug-Michelis (1999) p-values

Source: Researcher's Computation Using E-views

The Johansen method of cointegration was used for the study because all the variables are stationary at first difference. The Johansen result as displayed in table 4.3 clearly shows evidence of cointegration as the trace statistics test indicates 1 cointegrating equation as the trace statistic value is greater than that of $5 \%$ critical value $(75.29389>69.81889)$. Here, we reject the null hypothesis of no cointegration meaning that there exists a long-run relationship existing between the variables (BOP, EXR, IR, OPN, COP) under study. Given this, we can now run the unrestricted Vector Autoregression which is the Vector Error Correction Model (VECM). 
African Journal of Economics and Sustainable Development

ISSN: 2689-5080

Volume 4, Issue 2, 2021 (pp. 104-118)

\section{Vector Error Correction Mechanism (VECM)}

\section{TABLE 4.4}

Vector Error Correction Estimates

Date: 08/04/21 Time: 21:50

Sample (adjusted): 19842019

Included observations: 36 after adjustments

Standard errors in ( ) \& t-statistics in [ ]

\section{Cointegrating Eq: CointEq1}

\begin{tabular}{|c|c|c|c|c|c|}
\hline $\mathrm{BOP}(-1)$ & 1.000000 & & & & \\
\hline $\operatorname{EXR}(-1)$ & $\begin{array}{c}11.23226 \\
(2.14567) \\
{[5.23486]}\end{array}$ & & & & \\
\hline $\operatorname{IR}(-1)$ & $\begin{array}{r}-1.314774 \\
(14.2085) \\
{[-0.09253]}\end{array}$ & & & & \\
\hline OPN(-1) & $\begin{array}{r}-14554.01 \\
(2310.26) \\
{[-6.29974]}\end{array}$ & & & & \\
\hline $\mathrm{COP}(-1)$ & $\begin{array}{c}30.66194 \\
(8.18100) \\
{[3.74795]}\end{array}$ & & & & \\
\hline $\mathrm{C}$ & -389.5226 & & & & \\
\hline Error Correction: & $\mathrm{D}(\mathrm{BOP})$ & $\mathrm{D}(\mathrm{EXR})$ & $\mathrm{D}(\mathrm{IR})$ & $\mathrm{D}(\mathrm{OPN})$ & $\mathrm{D}(\mathrm{COP})$ \\
\hline CointEq1 & $\begin{array}{c}-0.262076 \\
(0.10260) \\
{[-2.55437]}\end{array}$ & $\begin{array}{r}-0.020339 \\
(0.00883) \\
{[-2.30214]}\end{array}$ & $\begin{array}{c}-1.14 \mathrm{E}-05 \\
(0.00209) \\
{[-0.00543]}\end{array}$ & $\begin{array}{c}4.80 \mathrm{E}-06 \\
(1.3 \mathrm{E}-05) \\
{[0.37163]}\end{array}$ & $\begin{array}{r}0.004646 \\
(0.00698) \\
{[0.66590]}\end{array}$ \\
\hline $\mathrm{D}(\mathrm{BOP}(-1))$ & $\begin{array}{c}0.359647 \\
(0.42030) \\
{[0.85568]}\end{array}$ & $\begin{array}{c}0.036082 \\
(0.03619) \\
{[0.99697]}\end{array}$ & $\begin{array}{r}0.008209 \\
(0.00857) \\
{[0.95778]}\end{array}$ & $\begin{array}{c}1.94 \mathrm{E}-05 \\
(5.3 \mathrm{E}-05) \\
{[0.36555]}\end{array}$ & $\begin{array}{c}0.001033 \\
(0.02858) \\
{[0.03613]}\end{array}$ \\
\hline $\mathrm{D}(\mathrm{BOP}(-2))$ & $\begin{array}{c}1.027424 \\
(0.41522) \\
{[2.47441]}\end{array}$ & $\begin{array}{c}0.044426 \\
(0.03575) \\
{[1.24254]}\end{array}$ & $\begin{array}{r}-0.004200 \\
(0.00847) \\
{[-0.49605]}\end{array}$ & $\begin{array}{r}-4.46 \mathrm{E}-05 \\
(5.2 \mathrm{E}-05) \\
{[-0.85318]}\end{array}$ & $\begin{array}{r}-0.030633 \\
(0.02824) \\
{[-1.08478]}\end{array}$ \\
\hline
\end{tabular}


African Journal of Economics and Sustainable Development

ISSN: 2689-5080

Volume 4, Issue 2, 2021 (pp. 104-118)

www.abjournals.org

\begin{tabular}{|c|c|c|c|c|c|}
\hline $\mathrm{D}(\operatorname{EXR}(-1))$ & $\begin{array}{c}2.396178 \\
(2.44480) \\
{[0.98011]}\end{array}$ & $\begin{array}{c}-0.075891 \\
(0.21052) \\
{[-0.36050]}\end{array}$ & $\begin{array}{r}-0.043258 \\
(0.04985) \\
{[-0.86772]}\end{array}$ & $\begin{array}{c}0.000235 \\
(0.00031) \\
{[0.76461]}\end{array}$ & $\begin{array}{r}0.307249 \\
(0.16627) \\
{[1.84791]}\end{array}$ \\
\hline $\mathrm{D}(\operatorname{EXR}(-2))$ & $\begin{array}{c}4.304821 \\
(2.65136) \\
{[1.62363]}\end{array}$ & $\begin{array}{c}0.299222 \\
(0.22830) \\
{[1.31062]}\end{array}$ & $\begin{array}{r}-0.015847 \\
(0.05406) \\
{[-0.29311]}\end{array}$ & $\begin{array}{c}-0.000112 \\
(0.00033) \\
{[-0.33635]}\end{array}$ & $\begin{array}{r}0.056715 \\
(0.18032) \\
{[0.31453]}\end{array}$ \\
\hline $\mathrm{D}(\mathrm{IR}(-1))$ & $\begin{array}{c}-7.338698 \\
(10.0134) \\
{[-0.73289]}\end{array}$ & $\begin{array}{r}-0.129036 \\
(0.86224) \\
{[-0.14965]}\end{array}$ & $\begin{array}{c}-0.528521 \\
(0.20418) \\
{[-2.58845]}\end{array}$ & $\begin{array}{c}-0.001365 \\
(0.00126) \\
{[-1.08232]}\end{array}$ & $\begin{array}{r}0.264859 \\
(0.68100) \\
{[0.38893]}\end{array}$ \\
\hline $\mathrm{D}(\operatorname{IR}(-2))$ & $\begin{array}{c}-2.540011 \\
(10.2794) \\
{[-0.24710]}\end{array}$ & $\begin{array}{r}-0.380442 \\
(0.88515) \\
{[-0.42981]}\end{array}$ & $\begin{array}{r}-0.171388 \\
(0.20961) \\
{[-0.81765]}\end{array}$ & $\begin{array}{c}-0.000888 \\
(0.00129) \\
{[-0.68536]}\end{array}$ & $\begin{array}{r}0.017816 \\
(0.69910) \\
{[0.02548]}\end{array}$ \\
\hline $\mathrm{D}(\mathrm{OPN}(-1))$ & $\begin{array}{c}7569.832 \\
(1894.96) \\
{[3.99473]}\end{array}$ & $\begin{array}{c}-74.77914 \\
(163.172) \\
{[-0.45828]}\end{array}$ & $\begin{array}{r}-21.84502 \\
(38.6404) \\
{[-0.56534]}\end{array}$ & $\begin{array}{c}-0.415173 \\
(0.23872) \\
{[-1.73916]}\end{array}$ & $\begin{array}{r}196.9955 \\
(128.874) \\
{[1.52858]}\end{array}$ \\
\hline $\mathrm{D}(\mathrm{OPN}(-2))$ & $\begin{array}{c}4138.636 \\
(1329.23) \\
{[3.11355]}\end{array}$ & $\begin{array}{r}-269.0617 \\
(114.458) \\
{[-2.35074]}\end{array}$ & $\begin{array}{r}-21.38934 \\
(27.1047) \\
{[-0.78914]}\end{array}$ & $\begin{array}{c}-0.149896 \\
(0.16745) \\
{[-0.89515]}\end{array}$ & $\begin{array}{r}224.8705 \\
(90.4002) \\
{[2.48750]}\end{array}$ \\
\hline $\mathrm{D}(\mathrm{COP}(-1))$ & $\begin{array}{r}-11.27844 \\
(4.02934) \\
{[-2.79908]}\end{array}$ & $\begin{array}{r}-0.238264 \\
(0.34696) \\
{[-0.68672]}\end{array}$ & $\begin{array}{c}-0.096458 \\
(0.08216) \\
{[-1.17398]}\end{array}$ & $\begin{array}{c}0.002277 \\
(0.00051) \\
{[4.48654]}\end{array}$ & $\begin{array}{r}-0.013843 \\
(0.27403) \\
{[-0.05051]}\end{array}$ \\
\hline $\mathrm{D}(\mathrm{COP}(-2))$ & $\begin{array}{r}-17.43505 \\
(5.20010) \\
{[-3.35283]}\end{array}$ & $\begin{array}{r}-0.548765 \\
(0.44777) \\
{[-1.22554]}\end{array}$ & $\begin{array}{c}0.076354 \\
(0.10604) \\
{[0.72007]}\end{array}$ & $\begin{array}{c}0.000782 \\
(0.00066) \\
{[1.19396]}\end{array}$ & $\begin{array}{r}-0.314382 \\
(0.35365) \\
{[-0.88895]}\end{array}$ \\
\hline $\mathrm{C}$ & $\begin{array}{r}-96.49327 \\
(46.7027) \\
{[-2.06612]}\end{array}$ & $\begin{array}{c}8.740776 \\
(4.02149) \\
{[2.17351]}\end{array}$ & $\begin{array}{c}1.077160 \\
(0.95232) \\
{[1.13109]}\end{array}$ & $\begin{array}{c}0.012099 \\
(0.00588) \\
{[2.05643]}\end{array}$ & $\begin{array}{r}-4.773453 \\
(3.17621) \\
{[-1.50288]}\end{array}$ \\
\hline R-squared & 0.726437 & 0.462566 & 0.341997 & 0.712314 & 0.357559 \\
\hline Adj. R-squared & 0.601054 & 0.216242 & 0.040412 & 0.580459 & 0.063107 \\
\hline Sum sq. resids & 969869.6 & 7191.257 & 403.2723 & 0.015392 & 4485.891 \\
\hline S.E. equation & 201.0255 & 17.30999 & 4.099148 & 0.025325 & 13.67158 \\
\hline F-statistic & 5.793744 & 1.877879 & 1.134000 & 5.402220 & 1.214320 \\
\hline Log-likelihood & -234.7070 & -146.4296 & -94.57146 & 88.55186 & -137.9349 \\
\hline Akaike AIC & 13.70594 & 8.801646 & 5.920637 & -4.252881 & 8.329717 \\
\hline Schwarz SC & 14.23378 & 9.329486 & 6.448476 & -3.725042 & 8.857557 \\
\hline Mean dependent & 89.07556 & 9.981831 & 0.196944 & 0.009652 & 0.963889 \\
\hline S.D. dependent & 318.2688 & 19.55266 & 4.184574 & 0.039098 & 14.12452 \\
\hline
\end{tabular}


Determinant resid covariance (dof

adj.)

Determinant resid covariance

Log-likelihood

Akaike information criterion

Schwarz criterion
4721612.

621776.1

$-495.5350$

31.14083

33.99996

Source: Researcher's Computation Using E-views

The result in table 4.4 is the output of the vector error correction mechanism. From the table, the error correction term (Cointeq1) yielded -0.262076 with a statistically significant p-value of $0.0174<0.05$. This is a long-run coefficient and it shows long-run causality running from EXR, IR, OPN and COP to BOP. The negative value which is desirous shows its ability to bounce back to equilibrium on account of any deviation.

The Short-run coefficients of the lag one and two of the balance of payments which yielded positive values entail that a percentage increase in them will lead to a percentage increase in current BOP by 0.36 and 1.02 per cent respectively.

The Short-run coefficients of the exchange rate (EXR) entail that a percentage increase in its first and second lag will lead to a percentage increase in the balance of payments (BOP) by 2.396178 and 4.304821 respectively. This conforms to economic a priori expectation because an increase in the exchange rate makes our exports attractive to other countries and this increase the balance of payments. The model further shows that a percentage increase in the first and second lag of interest rate will lead to a percentage decrease in the balance of payments by 7.338698 and 2.540011 respectively.

The Short-run coefficients of trade openness (OPN) entails that an increase in OPN lag one and lag two will lead to an increase in BOP by 7569.832 and 4138.636 respectively. This conforms to economic a priori expectation because the more strategically open an economy is, the more likely it will engage more in favourable international trade. Finally, the VECM estimates show that a percentage increase in the first and second lags of crude oil price will lead to a percentage decrease in BOP by 17.43505 and 96.49327 respectively.

The R-squared value yielded 0.726437 which is more than $60 \%$. This means that the explanatory power of the independent variables is high. It practically entails that variations in the dependent variable are explained by changes in the independent variable by approximately 72.64\%. This shows the model has good fitness.

The F-statistics is a statistical tool employed in checking the statistical significance of the entire regression plane. From the regression, it can be clearly seen that the probability value of the Fstatistics yielded 5.793744. This means that the test is statistically significant in the entire regression plane. It further entails that exchange rate, interest rate, trade openness and crude oil prices jointly influence the balance of payments significantly. 


\section{Diagnostic Tests}

\section{Block-Wald Causality Test}

Table 4.6

VEC Granger Causality/Block Exogeneity Wald

Tests

Date: 07/08/21 Time: 02:25

Sample: 19812019

Included observations: 36

Dependent variable: $\mathrm{D}(\mathrm{BOP})$

\begin{tabular}{cccc}
\hline Excluded & Chi-sq & Df & Prob. \\
\hline & & & \\
D(EXR) & 4.970305 & 2 & 0.0833 \\
D(IR) & 0.554927 & 2 & 0.7577 \\
D(OPN) & 18.46026 & 2 & 0.0001 \\
D(COP) & 15.96662 & 2 & 0.0003 \\
\hline All & 33.21791 & 8 & 0.0001 \\
\hline
\end{tabular}

Source: Researcher's Computation Using E-views

From table 4.6, it can be clearly seen that the Chi-Square probability of exchange rate yielded $0.0833>0.05$. This entails that the exchange rate (EXR) does not have any causal effect on the balance of payments. The table also reveals that interest rate does have any causal effect on the balance of payments because its Chi-Square probability yielded $0.7577>0.05$. The Chi-Square probability of trade openness $(\mathrm{OPN})$ yielded $0.00001<0.05$. This entails that trade openness has a causal effect on the balance of payments. From the table, we can conclude that crude oil price (COP) has a causal effect on the balance of payments because its Chi-Square probability yielded $0.0001<0.05$. Jointly, EXR, IR, OPN and COP have short-run causal effects on the balance of payments. 
Model Stability (AR Unit-Circle)

Table 4.7

Inverse Roots of AR Characteristic Polynom

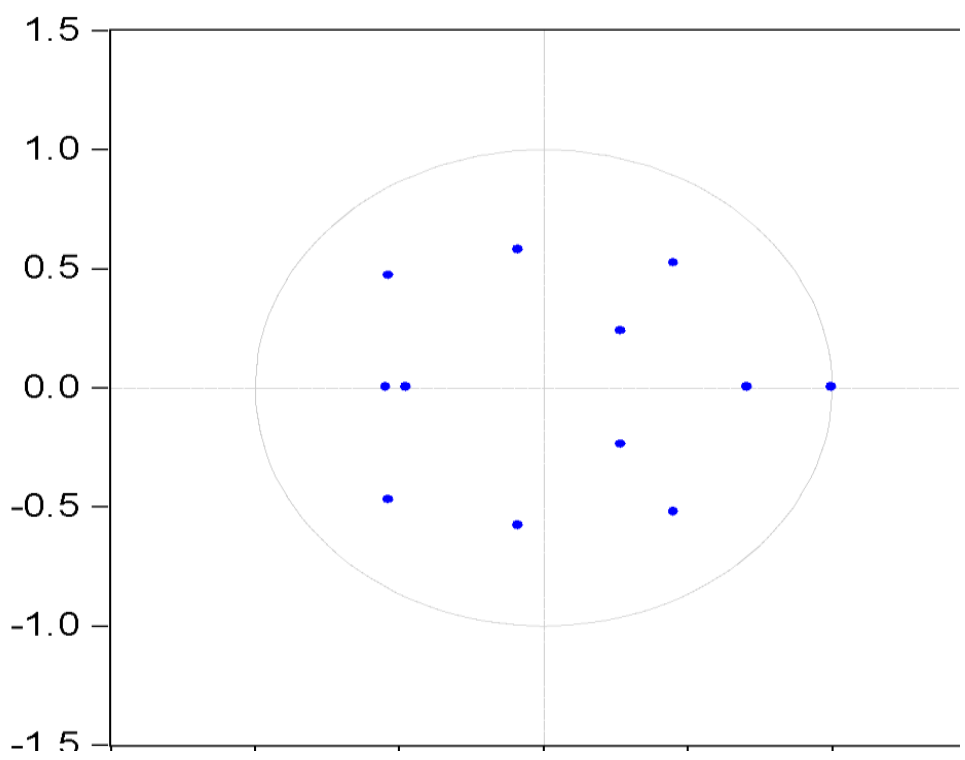

Source: Researcher's Computation Using E-views, 10.

There is a need to carry out a stability diagnostic to make sure the model is dynamically stable. The condition for stability is that no inverse root dot should be outside the unit circle. Judging from the inverse roots of the AR characteristic polynomial, the model is stable as no dot lies outside the enclave of the unit circle.

\section{Serial Correlation Test}

Table 4.8

Breusch-Godfrey Serial Correlation LM Test:

$\begin{array}{llll}\text { F-statistic } & 1.200195 & \text { Prob. F(2,22) } & 0.3201 \\ \text { Obs*R-squared } & 3.541502 & \text { Prob. Chi-Square(2) } & 0.1702\end{array}$

Source: Researcher's Computation Using E-views 
The serial correlation test was carried out to ascertain the presence of serial correlation in our model. However, it is recalled that the null hypothesis states that there is no serial correlation. Based on the serial correlation test, it can be clearly seen that the probability of Chi-Square yielded $0.1702>0.05$. This entails the acceptance of the null hypothesis and we, therefore, conclude that there is no evidence of serial correlation in our residuals.

\section{Heteroscedasticity Test (Breusch-Pagan-Godfrey)}

\section{Table 4.9}

Heteroskedasticity Test: Breusch-Pagan-Godfrey

$\begin{array}{llll}\text { F-statistic } & 0.894963 & \text { Prob. F(15,20) } & 0.5803 \\ \text { Obs*R-squared } & 14.45888 & \text { Prob. Chi-Square(15) } & 0.4910 \\ \text { Scaled explained SS } & 11.76427 & \text { Prob. Chi-Square(15) } & 0.6968\end{array}$

Source: Researcher's Computation Using E-views 10.

The heteroscedasticity test was carried out to ascertain the presence of homoscedasticity in our model. The probability of the Chi-Square yielded $0.4910>0.05$ and this means that there is no evidence of heteroscedasticity in our residuals. This is good and desirable.

\section{Normality Test (Jaque-Berra)}

Table 4.10

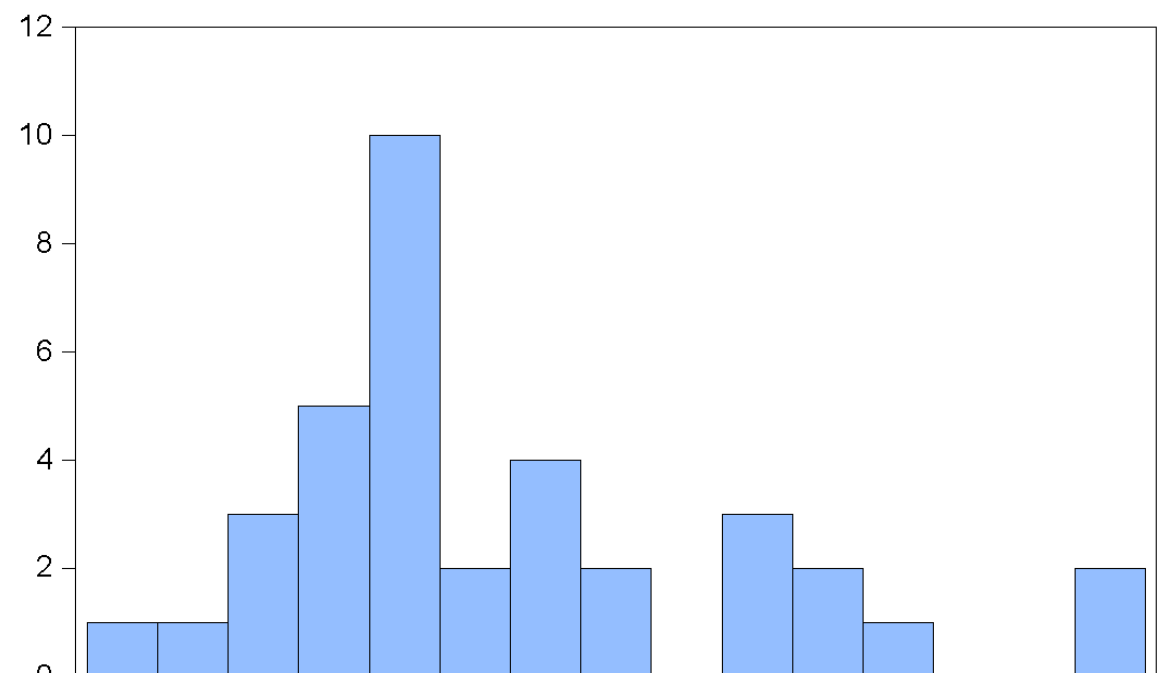

Series: Residuals Sample 19842019 Observations 36

Mean $1.46 \epsilon$

Median $-0.11 \mathrm{~s}$ Maximum $\quad 0.891$ Minimum $\quad-0.585$ Std. Dev. $\quad 0.34 \varepsilon$ Skewness $\quad 0.967$ Kurtosis $\quad 3.344$ Jarque-Bera $\quad 5.797$ Probability $\quad 0.055$

Source: Researcher's Computation Using E-views 
The normality test was carried out to ascertain if the residuals are normally distributed. The probability value of the Jarque-Bera yielded 0.055083 which is obviously greater than 0.05 . This compels us to accept the null hypothesis of normal distribution. Hence, we conclude that the residuals are normally distributed.

\section{DISCUSSION OF RESULTS}

The analysis conducted so far showed that the exchange rate has had a positive and significant impact on the balance of payments in Nigeria for the years under analysis. It entails that an increase in the exchange rate is not entirely bad for Nigeria's balance of payments and trade experience. This further implies that one of the major causes of poor trade experienced by Nigeria is a fluctuating exchange rate. Hence; Nigeria has the potentials of experiencing a tremendous increase in exports if the federal government can through the monetary authorities stabilize the level of the exchange rate. This finding is in line with the findings of Mbanasor and Obioma (2017), Dayo and Akindele (2016), Oladipupo (2015), etc. The granger causality analysis conducted also revealed that there exists no causality relationship between exchange rate and balance of payments in Nigeria. This implies that over the years, is no connection between exchange rate fluctuations and the balance of payments in Nigeria. This is in line with the assertions of Okoli (2018) who posited that exchange rate fluctuations have a negative and disconnection with an increase in exports.

\section{CONCLUSION}

This study analysed the effect of the exchange rate on the balance of payments of Nigeria between 1981 and 2019. Based on the findings derived from the study, it was concluded that Nigeria has the potentials to tremendously boosting its exports and maintaining a favourable balance of payments through pursuing devaluation and setting export promotion industries.

\section{RECOMMENDATIONS}

In connection to the findings of this research, the following recommendations are suggested:

1. To sustain a strong Naira, the Nigerian government should channel its monetary and fiscal instruments in boosting national productivity. This will go a long way in stabilizing the exchange rate and sustaining a favourable balance of payments.

2. Stable political and industrial conditions and peace and security in a country have a significant influence on the exchange rate. Therefore, the Nigerian government should make political and industrial stability a policy priority. 


\section{REFERENCES}

CBN (2017). Central Bank of Nigeria Annual Reports and Statement of Accounts, CBN Abuja, Nigeria.

CBN (2018). Central Bank of Nigeria Annual Reports and Statement of Accounts, CBN Abuja, Nigeria.

Dayo, W. \& Akindele, K.O (2016). The Effects of Exchange Rate Policy on Nigeria's agricultural competitiveness." African Economic Research Consortium AERC/CKEA Nairobi, Research paper 42; 52.

Echekoba, D.D (2016). The impact of exchange rate volatility on South African exports. Mediterranean Journal of Social Sciences, 4(2), 507-513.

Imoisi, A.I. (2012). Trends in Nigeria's balance of payments: an empirical analysis from 1970-2010, European Journal of Business and Management, 4(21), pp. 210-217.

Mbanasor, V. \& Obioma, O.P (2017). Exchange rate volatility and non-oil exports in Nigeria: 1986 - 2008. International Business and Management, 9(3), 70-79.

Nnanna, O. (2004). Foreign private investment in Nigeria. Economic and Financial Review, 41(4), pp. 87-95.

Nwanosike, D. U.; Uzoechina, B. Ebenyi, G. O. \& Ishiwu,V. (2017). Analysis of balance of payments trend in Nigeria: A test of Marshall-Lerner hypothesis. Saudi Journal of Business and Management Studies, 2(5), pp. 468-474

Ogbonna, B. C. (2010). Financial development, trade openness and economic growth in a small open economy: Evidence from Botswana. Journal of Banking, 4(1), pp. 59-76.

Oladipupo, A. O. \& Ogebenovo, F. O. (2011). Impact of exchange rate on the balance of payment in Nigeria. An International Multidisciplinary Journal, 5(4), pp. 73-88.

Olanipekun, D. B. \& Ogunsola, A.J. (2017). Balance of payment crises in Nigeria: The role of the exchange rate. International Journal of Economics, Commerce and Management,5(5), pp. 119-140.

Onoh, J. K. (2002). Dynamics of money, banking and finance in Nigeria. An Emerging Market, Aba: Astra Meridian.

Shafi, K.; Hua, L.; Idrees, I. \& Nazeer, A. (2015). Impact of the exchange rate, inflation rate and interest rate on the balance of payment: A study from India and Pakistan. American Journal of Business, Economics and Management,3(1), pp. 9-13. 